\title{
PERAN PENGENDALIAN ANGGARAN KETAT DAN ETIKA MEMODERASI PENGARUH PARTISIPASI PENGANGGARAN PADA SENJANGAN ANGGARAN
}

\author{
I Putu Adnyana Putra ${ }^{1}$ \\ Ni Ketut Rasmini ${ }^{2}$ \\ Ida Bagus Putra Astika ${ }^{3}$ \\ ${ }_{1}^{1}$ Fakultas Ekonomi dan Bisnis, Universitas Udayana, Bali, Indonesia
email : adnyana1406@ gmail.com
${ }^{2}$ Fakultas Ekonomi dan Bisnis, Universitas Udayana, Bali, Indonesia
${ }^{3}$ Fakultas Ekonomi dan Bisnis, Universitas Udayana, Bali, Indonesia
}

\begin{abstract}
ABSTRAK
Penelitian ini menyelidiki apakah pengendalian anggaran ketat dan etika memoderasi pengaruh partisipasi penganggaran pada senjangan anggaran. Penelitian dilakukan di 39 Satuan Kerja Perangkat Daerah pada Pemerintah Daerah Kabupaten Tabanan. Sampel yang digunakan ditentukan dengan metode disproportionate stratified random sampling. Pengumpulan data berupa survey dengan cara menyebar sejumlah kuesioner. Responden yang diambil sebanyak 273 orang pejabat struktural eselon II, III dan IV. Hasil analisis regresi moderasi menunjukkan bahwa pengendalian anggaran ketat dapat memperlemah pengaruh partisipasi penyusunan anggaran pada senjangan anggaran. Etika dapat memperlemah pengaruh partisipasi penyusunan anggaran pada senjangan anggaran.
\end{abstract}

Kata kunci : Partisipasi Penganggaran, Pengendalian Anggaran Ketat, Etika, Senjangan Anggaran

\begin{abstract}
This study to examine that tight budget control and ethics climate as a moderation variabels influence the partisipative budgeting on budgetary slack. The research was conducted at 39 SKPD in Tabanan regency. The Sample was taken by disproportionate stratified random sampling. Data collected by survey with distributing questionnaires. The respondents as many as 273 officials from echelon II, III and IV. The regression analysis shows that the moderation of tight budgetary control were able to weaken the effect of budgetary participation on budgetary slack. Ethics able to weaken the effect of budgetary participation on budgetary slack.
\end{abstract}

Keywords: Participative Budgeting, Tight Budget Control, Ethics, Budgetary Slack 
I Pt. Adnyana Putra, Ni Kt. Rasmini dan IB. Putra Astika. Peran Pengendalian.......

\section{PENDAHULUAN}

Lingkungan bisnis yang berubah dengan sangat cepat menjadikan suatu entitas memiliki strategi untuk tetap bertahan dan berkembang, dan strategi yang dibangun akan tertuang dalam anggaran, baik jangka pendek, menengah maupun jangka panjang. Anggaran merupakan rencana pendapatan dan belanja yang bersifat komprehensif pada bagian yang ada sesuai dengan wewenang dan tanggungjawabnya, dan juga dapat berfungsi sebagai alat untuk menilai kinerja. Anggaran juga dapat digunakan sebagai target terlaksananya berbagai program/kegiatan yang telah disusun dalam perencanaan jangka pendek maupun jangka panjang.

Anggaran sektor publik mencakup rencana kegiatan yang direpresentasikan dalam bentuk rencana perolehan pendapatan dan belanja dalam satuan moneter (Mardiasmo, 2009). Dalam bentuk sederhana, anggaran sektor publik adalah suatu dokumen yang menggambarkan kondisi keuangan yang meliputi informasi terkait pendapatan, belanja dan kegiatan. Program/kegiatan yang akan dilakukan dalam suatu organisasi diestimasikan dalam suatu anggaran.

Penyusunan anggaran pada sektor publik merupakan kegiatan penting, kompleks, dan melibatkan proses politik yang rumit serta melibatkan banyak pihak beserta kepentingannya masing-masing. Untuk mengefektifkan penyusunan anggaran diperlukan perkiraan tentang kondisi yang akan datang. Argyris (1952) menyatakan fokus utama kinerja yang efektif adalah tercapainya tujuan anggaran dan partisipasi 
memiliki peran penting dalam mewujudkan anggaran tersebut. Partisipasi dalam penyusunan anggaran (penganggaran) dapat memberi informasi tambahan yang dapat mengurangi ambiguitas peran dan mampu mendukung peningkatan kinerja (Chenhall dan Brownell, 1988).

Partisipasi dalam penyusunan anggaran adalah proses dimana para individu, yang kinerjanya akan dinilai dan memperoleh penghargaan berdasarkan capaian target anggaran, terlibat dan berpengaruh dalam penyusunan target anggaran (Brownell, 1982). Partisipasi memberikan kewenangan kepada para manajer pusat pertanggungjawaban untuk menetapkan isi dari anggarannya, tetapi pemberian kewenangan memungkinkan kesempatan bagi para partisipan untuk menyalahgunakan kewenangannya dengan memudahkan pencapaian anggaran sehingga dapat merugikan organisasi (Sujana, 2010). Anggreni (2008) menyatakan terdapat konsekuensi yang muncul sebagai akibat pola penganggaran partisipatif yaitu perilaku yang negatif dan perilaku yang positif. Perilaku positif berupa peningkatan kinerja karena termotivasi bahwa anggaran merupakan instrumen untuk menilai kinerja. Tetapi ketika anggaran dianggap sebagai beban kerja dan target yang harus dicapai, maka akan menimbulkan perilaku negatif berupa senjangan anggaran (budgetary slack).

Senjangan anggaran adalah perbedaan jumlah anggaran yang ditetapkan bawahan dengan estimasi terbaik dari organisasi. Senjangan anggaran dibuat dengan menetapkan target anggaran yang tidak sesuai dengan estimasi terbaik yang 
I Pt. Adnyana Putra, Ni Kt. Rasmini dan IB. Putra Astika. Peran Pengendalian.......

seharusnya, berupa penetapan target pendapatan yang rendah dan penetapan target belanja yang relatif tinggi, yang menjadikan target anggaran lebih mudah untuk dicapai. Senjangan anggaran menyebabkan bias terhadap anggaran dan mampu menurunkan efektivitas organisasi.

Hilton dalam Hermanto (2003) menyebutkan terdapat 3 alasan utama individu cenderung menciptakan senjangan anggaran, yaitu; (1) individu percaya bahwa kinerja mereka akan terlihat bagus bagi atasan, jika mereka dapat mencapai target anggaran, (2) senjangan anggaran selalu dipakai untuk mengatasi kondisi yang tidak pasti, jika tidak ada kejadian yang tidak terduga maka target anggaran dapat terlampaui, (3) target anggaran sering kali dipotong dalam proses pengalokasian sumber daya.

Salah satu indikasi senjangan anggaran pada sektor publik adalah adanya sumber pendapatan yang berasal dari Sisa Lebih Perhitungan Anggaran tahun sebelumnya (SiLPA), dimana SiLPA berasal dari realisasi pendapatan yang lebih besar dari target pendapatan, ataupun dari kekurang mampuan dalam memaksimalkan penyerapan anggaran belanja daerah (Widanaputra dan Mimba, 2014). Penciptaan senjangan anggaran pada sektor publik tidak cukup dikurangi dengan sistem pengendalian manajemen organisasi sektor publik. Hal ini mengindikasikan bahwa senjangan anggaran harus ditangani oleh semua aspek, dan perlunya ditelaah kembali faktor-faktor yang menyebabkan penciptaan senjangan anggaran pada organisasi sektor publik. 
Kabupaten Tabanan dalam proses perencanaan dan penyusunan anggaran menerapkan pola penganggaran partisipatif. Salah satu hal yang menjadi indikasi adanya partisipasi anggaran pada Pemerintah Kabupaten Tabanan adalah dengan dibentuknya tim anggaran pemerintah daerah (TAPD). Sesuai dengan Pemendagri No. 13 Tahun 2006 tentang Pedoman Pengelolaan Keuangan Daerah, TAPD adalah tim yang dibentuk dengan keputusan kepala daerah dan dipimpin oleh sekretaris daerah yang mempunyai tugas menyiapkan serta melaksanakan kebijakan kepala daerah dalam rangka penyusunan APBD yang anggotanya terdiri dari pejabat perencana daerah, pejabat pengelola keuangan daerah (PPKD) dan pejabat lain sesuai dengan kebutuhan. PPKD dapat melimpahkan kepada pejabat lainnya dilingkungan Satuan Kerja Perangkat Daerah (SKPD) untuk melaksanakan tugas, antara lain: menyusun rancangan APBD dan rancangan perubahan APBD, melakukan pengendalian pelaksanaan APBD, melaksanakan pemungutan pajak daerah, dan menyajikan informasi keuangan daerah.

Penelitian tentang pengaruh partisipasi penganggaran pada senjangan anggaran telah banyak dilakukan dan masih menjadi topik utama khususnya dalam anggaran sektor publik. Penelitian yang dilakukan oleh Young (1985), Lukka (1988), Latifah (2010), Little, et al, (2002), Aprila dan Hidayani (2012), Latifah (2010), Widanaputra dan Mimba (2014) menunjukkan bahwa partisipasi anggaran yang tinggi menyebabkan terjadinya senjangan anggaran. Berbeda dengan penelitian yang dilakukan oleh Schift dan Lewin (1970), Onsi (1973), Merchant (1985), Dunk (1993), 
I Pt. Adnyana Putra, Ni Kt. Rasmini dan IB. Putra Astika. Peran Pengendalian.......

Latuheru (2006), serta Supanto (2010) membuktikan bahwa partisipasi anggaran yang tinggi mampu menurunkan terjadinya senjangan anggaran.

Ketidakkonsistenan hasil penelitian mengindikasikan perlu adanya pendekatan kontijensi (contingency approach) terkait hubungan partisipasi penyusunan anggaran dengan senjangan anggaran yang dipengaruhi oleh beberapa faktor atau variabel yang bersifat kondisional. Salah satu variabel kondisionalnya adalah variabel pemoderasi yang merupakan variabel yang mampu memperkuat atau memperlemah hubungan antara variabel bebas dengan variabel terikat (Sugiyono, 2014)

Tujuan penelitian ini adalah untuk memperoleh bukti empiris peran pengendalian anggaran ketat dan etika memoderasi pengaruh partisipasi penganggaran pada senjangan anggaran. Berdasarkan tujuan tersebut diharapkan penelitian ini dapat menjadi bahan masukan kepada Pemerintah Kabupaten Tabanan dalam proses penyusunan anggaran, agar anggaran yang disusun dapat lebih efektif dan efisien serta senjangan anggaran yang sering muncul akibat proses penganggaran partisipatif dapat lebih diminimalkan.

Agency theory yang merupakan konsep yang menjelaskan hubungan kontraktual antara pemberi mandat (principal) dan penerima mandat (agent) (Jansen dan Meckling, 1976). Dalam hubungan kontraktual ini terjadi pendelegasian wewenang. Dalam penganggaran sektor publik terjadi hubungan keagenan antara lain antara legislatif dan publik, antara eksekutif dan legislatif, antara kepala daerah dan kepala SKPD. Agency theory menjelaskan bahwa pihak-pihak yang terlibat dalam 
penganggaran memiliki kecenderungan untuk memaksimalkan utilitasnya melalui pengalokasian sumber daya dalam anggaran yang ditetapkan (Magner \& Johnson, 1995). SKPD sebagai agen yang mengusulkan anggaran dan juga pelaksana dari anggaran berupaya memaksimalkan jumlah anggaran dengan menciptakan senjangan anggaran.

Pengendalian anggaran ketat merupakan suatu cara pengendalian di dalam suatu unit organisasi dengan membentuk standar target terkait pendapatan dan pembiayaan serta pemantauan kinerja secara berkesinambungan dengan membandingkan anggaran dengan aktualisasinya, disamping itu pengendalian yang efektif menjadi penting dalam rangka mencapai tujuan organisasi. Lukka (1988) menyebutkan dalam konteks penyusunan anggaran, senjangan anggaran dibuat dengan menetapkan target anggaran agar menjadi lebih mudah untuk dicapai. Rasionalitas manajemen organisasi dapat ditingkatkan agar sistem pengendalian anggaran menjadi efektif dengan cara mengurangi kebebasan manajer dalam mencapai tujuan anggaran (Halioui dan Leclere, 2008). Williamson (1964) menyatakan pengendalian anggaran yang ketat meningkatkan kemungkinan senjangan anggaran dapat dideteksi sehingga dapat dibatasi.

Dunk (1993) dan Merchant (1985) menemukan bahwa senjangan anggaran cenderung menurun pada saat pengendalian anggaran ditingkatkan. Dalam hal ini ditemukan bukti empiris yang menyatakan pengendalian anggaran memiliki hubungan negatif dengan senjangan anggaran. 
I Pt. Adnyana Putra, Ni Kt. Rasmini dan IB. Putra Astika. Peran Pengendalian.......

$\mathrm{H}_{1}$ : Pengendalian anggaran ketat memperlemah pengaruh partisipasi penganggaran pada senjangan anggaran.

Senjangan anggaran dapat diartikan tindakan bawahan yang memperkecil kapabilitas produktifnya saat diberikan kewenangan untuk menentukan standar kinerjanya (Young, 1985). Senjangan anggaran dapat timbul pada saat manajer dengan sengaja menentukan target pendapatan yang rendah (understate revenue) dan target biaya yang tinggi (overstate cost). Kondisi tersebut dilakukan dengan tujuan untuk mempermudah manajer dalam pencapaian target anggaran sehingga menimbulkan kesan bahwa manajer tersebut memiliki kinerja yang baik.

Alasan dilakukannya senjangan anggaran oleh para manajer adalah untuk menyediakan suatu margin keselamatan (margin of safety) untuk memenuhi tujuan yang dianggarkan (Faruq, 2013). Pusat pertanggungjawaban dalam menetapkan isi dari anggaran menjadi kewenangan para manajer ketika dilibatkan dalam partisipasi penganggaran. Pemberian kewenangan ini memberi kesempatan bagi para partisipan untuk menyalahgunakan kewenangan yang dimiliki dengan memudahkan pencapaian anggaran sehingga dapat merugikan perusahaan (Sujana, 2010).

Penelitian Gokhan (2011) menemukan bahwa nilai etika dalam organisasi dan perilaku berpengaruh dalam proses penyusunan anggaran. Nilai etika bawahan yang tinggi memungkinkan penciptaan senjangan anggaran yang rendah. Lingkup etika dalam penelitian ini yaitu etika umum yang merupakan kondisi dasar bagaimana manusia bertindak dengan etis, bagaimana manusia mengambil keputusan secara etis, 
teori-teori etika serta prinsip moral dasar yang menjadi panduan individu dalam bertindak dan tolak ukur dalam menilai baik atau buruknya sebuah tindakan. Maskun (2009) menemukan bukti empiris bahwa etika berpengaruh positif pada senjangan anggaran.

$\mathrm{H}_{2}$ : Etika pegawai memperlemah pengaruh partisipasi penganggaran pada senjangan anggaran.

\section{METODE PENELITIAN}

Penelitian ini memakai data primer yang diperoleh dengan survey berupa penyebaran kuesioner. Pengambilan sampel dengan teknik disproportionate stratified random sampling. Penyebaran kuesioner dilakukan pada 39 SKPD di lingkungan Pemerintah Kabupaten Tabanan. Populasi penelitian sebanyak 667 orang pejabat struktural. Jumlah sampel yang diambil sebanyak 273 orang pejabat struktural eselon II yaitu Kepala Dinas/Badan/Inspektorat, eselon III yaitu Sekretaris Dinas/Badan/Inspektorat, Kepala Bagian, Camat, Kepala Bidang, dan eselon IV yaitu Kepala Sub. Bagian, Kepala Sub. Bidang.

Variabel yang digunakan berupa partisipasi penganggaran sebagai variabel bebas, senjangan anggaran sebagai variabel terikat, serta pengendalian anggaran ketat dan etika sebagai variabel pemoderasi. Partisipasi penganggaran menjelaskan tentang tingkat keterlibatan dan pengaruh individu dalam menentukan dan menyusun anggaran yang ada pada organisasi baik secara periodic maupun tahunan. Partisipasi penganggaran dinyatakan dengan tiga indikator: (a) keikutsertaan dalam penyusunan 
I Pt. Adnyana Putra, Ni Kt. Rasmini dan IB. Putra Astika. Peran Pengendalian.......

anggaran, (b) keterlibatan dalam pembahasan usulan dengan tim anggaran, dan (c) kontribusi dalam penyusunan anggaran.

Senjangan anggaran merupakan kecenderungan dalam proses penyusunan anggaran untuk tidak mengungkapkan kemampuan optimal dalam komposisi anggaran. Indikator senjangan anggaran: (a) perbedaan jumlah anggaran yang dinyatakan dengan estimasi terbaik, (b) kelonggaran dalam anggaran, (c) standar anggaran, dan (d) keinginan dalam pencapaian target anggaran. Pengendalian anggaran ketat didasarkan pada evaluasi kinerja manajer dalam pencapaian tujuan anggaran dalam suatu periode akuntansi yang berarti bahwa pengendalian anggaran ketat menekankan pada pencapaian anggaran (Anthony dan Govindarajan, 2006). Indikator yang digunakan untuk pengendalian anggaran ketat, berupa: (a) penekanan dalam pencapaian anggaran, (b) tidak mudah menerima revisi anggaran dalam satu tahun anggaran,( c) fokus pimpinan pada rincian anggaran, (d) tidak mudah mentolerir penyimpangan target anggaran interim, (e) pimpinan secara intensif terlibat dalam komunikasi terkait anggaran.

Etika dalam sektor publik merupakan acuan, referensi, dan petunjuk tentang yang seharusnya dilakukan oleh aparatur pemerintah dalam rangka menjalankan kebijakan-kebijakan publik, dan dapat digunakan sebagai standar penilaian apakah perilaku aparatur pemerintah dalam menjalankan kebijakan-kebijakan publik dapat dikatakan baik atau buruk (Widodo, 2001). Indikatornya adalah etika umum dengan memperhatikan kondisi dasar pegawai, bertindak dengan etis, mengambil keputusan 
secara etis, serta prinsip-prinsip moral dasar dalam menilai baik atau buruknya sebuah tindakan.

Skala pengukuran yang digunakan pada penelitian ini adalah skala likert (skala bertingkat) dengan lima alternatif jawaban dan masing-masing jawaban diberi skor. Selanjutnya, data dari kuesioner dikonversi menggunakan Method of Successive Interval menjadi data kuantitatif. Metode analisis data menggunakan analisis regresi moderasi yang sebelumnya dilakukan uji asumsi klasik (uji normalitas, uji multikolonieritas, uji heterokedastisitas), uji reliabilitas dan uji validitas. Uji tersebut dilakukan untuk menguji kesahihan nilai parameter yang dihasilkan oleh model. Model persamaan regresi penelitian:

$$
\mathrm{SA}=\mathrm{b}_{0}+\mathrm{b}_{1} \mathrm{PP}+\mathrm{b}_{2} \mathrm{PAK}+\mathrm{b}_{3} \mathrm{ET}+\mathrm{b}_{4} \mathrm{PP} * \mathrm{PAK}+\mathrm{b}_{5} \mathrm{PP} * \mathrm{ET}+\mathrm{e}
$$

Ket. :

\begin{tabular}{|c|c|}
\hline SA & $=$ senjangan anggaran \\
\hline $\mathrm{b}_{0}$ & $=$ konstanta \\
\hline$b_{1-5}$ & $=$ koefisien regresi \\
\hline $\mathrm{PP}$ & $=$ partisipasi penganggaran \\
\hline PAK & $=$ pengendalian anggaran ketat \\
\hline ET & $=$ etika \\
\hline PP*PAK & $\begin{aligned}= & \text { moderasi antara partisipasi penganggaran } \\
& \text { pengendalian anggaran ketat }\end{aligned}$ \\
\hline PP*ET & $\begin{array}{l}=\text { moderasi antara partisipasi penganggaran dengan etika } \\
=\text { residual }\end{array}$ \\
\hline
\end{tabular}

Uji kelayakan model (uji F) dimaksudkan untuk menguji apakah model regresi yang digunakan layak (fit) atau tidak layak. Uji F dilakukan dengan melihat nilai signifikansi F dengan level signifikansi $\alpha=5 \%$. Model regresi dianggap layak uji bila 
I Pt. Adnyana Putra, Ni Kt. Rasmini dan IB. Putra Astika. Peran Pengendalian.......

hubungan antar variabel bebas signifikan mempengaruhi variabel terikat. Model regresi dinyatakan fit bila hasil $\mathrm{F}$ test menunjukkan signifikan atau $\mathrm{P}$ value $<0,05$.

Koefisien determinasi $\left(\mathrm{R}^{2}\right)$ dipakai untuk mengukur seberapa besar kemampuan model untuk menjelaskan variasi variabel terikat. Koefisien determinasi $\left(\mathrm{R}^{2}\right)$ dapat diinterpretasikan bahwa sebesar $\left(\mathrm{R}^{2} \times 100 \%\right)$ variasi dari variabel dependen mampu dijelaskan oleh variabel bebas, sedangkan sisanya sebesar $\left(100 \%-R^{2} \times 100 \%\right)$ dipengaruhi oleh variabel lain di luar model.

Uji statistik $\mathrm{t}$ bertujuan untuk menguji pengaruh variabel bebas terhadap variabel terikat. Hipotesis masing-masing variabel bebas diterima apabila nilai signifikansinya $<0,05$, sebaliknya jika nilai signifikasi $>0,05$ maka hipotesis ditolak.

\section{HASIL DAN PEMBAHASAN}

Data penelitian dikumpulkan dengan mengirimkan sebanyak 273 kuesioner kepada responden pada masing-masing SKPD pada pemerintah Kabupaten Tabanan. Tahap penyebaran kuesioner dilakukan bulan September 2016 hingga Oktober 2016 dengan cara mengantarkan langsung kuesioner kepada masing-masing unit kerja responden dengan menetapkan waktu pengembalian kuesioner selama satu minggu sejak kuesioner disebarkan kepada responden atau sesuai dengan kesepakatan yang ditetapkan antara responden dengan peneliti. Dalam prosesnya, pengembalian kuesioner terbagi menjadi 3 tahapan, yaitu: pengembalian tahap pertama pada minggu pertama setelah penyebaran kuesioner, tahap kedua pada minggu kedua setelah penyebaran kuesioner, tahap ketiga pada minggu ketiga setelah penyebaran 
kuesioner, serta terdapat responden yang tidak mengembalikan kuesioner sampai batas waktu yang ditetapkan peneliti. Dari 273 kuesioner yang disebarkan, sebanyak 13 kuesioner tidak kembali karena alasan kesibukan responden, sebanyak 7 kuesioner tidak digunakan karena tidak lengkap, sehingga hanya 253 kuesioner yang dapat digunakan dan diolah lebih lanjut.

Deskripsi profil responden ditunjukkan pada Tabel 1.

Tabel 1

Profil Responden

\begin{tabular}{lcr}
\hline \multicolumn{1}{c}{ Keterangan } & Jumlah & Persentase \\
\hline Jenis Kelamin & & \\
Laki-laki & 173 & $68,38 \%$ \\
Perempuan & 80 & $31,62 \%$ \\
Total & 253 & $100,00 \%$ \\
Umur & & \\
$<40$ tahun & 28 & $11,07 \%$ \\
$40 \quad-50$ tahun & 113 & $44,66 \%$ \\
$>50$ tahun & 112 & $44,27 \%$ \\
Total & 253 & $100,00 \%$ \\
Jabatan & & \\
Eselon II & 23 & $9,09 \%$ \\
Eselon III & 102 & $40,32 \%$ \\
Eselon IV & 128 & $50,59 \%$ \\
Total & 253 & $100,00 \%$ \\
Masa Jabatan & & \\
$<1$ tahun & - & $41,11 \%$ \\
$1-2$ tahun & 104 & $20,16 \%$ \\
$3-4$ tahun & 51 & $38,73 \%$ \\
$>4$ tahun & 98 & $100,00 \%$ \\
Total & 253 & \\
Pendidikan & & $28,85 \%$ \\
S-2 & 73 & $64,03 \%$ \\
S-1 & 162 & $1,98 \%$ \\
Diploma & 5 & $5,14 \%$ \\
SMA & 13 & $100,00 \%$ \\
Total & 253 & \\
\hline Sumber: data diolah, 2016 & & \\
& &
\end{tabular}

Tabel 1 menunjukkan keterlibatan gender dalam penyusunan anggaran, dimana sebagian besar responden pada penelitian ini berjenis kelamin laki-laki sebanyak 173 
I Pt. Adnyana Putra, Ni Kt. Rasmini dan IB. Putra Astika. Peran Pengendalian.......

orang $(63,38 \%)$ responden, sedangkan responden dengan jenis kelamin perempuan sebanyak 80 orang $(31,62 \%)$. Kondisi tersebut menggambarkan laki-laki lebih dominan dalam proporsi sampel pegawai yang menduduki jabatan struktural yang berkaitan dengan partisipasi penyusunan anggaran pada masing-masing SKPD.

Umur responden menggambarkan tingkat kedewasaan pada pejabat yang barkaitan dengan partisipasi penganggaran sehingga diharapkan memiliki kematangan dalam berpikir dan mengambil keputusan sesuai dengan etika dan norma umum yang berlaku. Maka karena itu dirasa penting untuk mencantumkan umur sebagai salah satu ukuran dalam mengidentifikasi responden. Tabel 1 menunjukkan responden dengan umur lebih kecil dari 40 tahun sebanyak 28 orang (11,07\%), responden dengan umur 40 hingga 50 tahun 113 orang (44,66\%), dan responden yang berumur diatas 50 tahun sebanyak 112 orang $(44,27 \%)$. Hal tersebut juga menjadi sebuah gambaran bahwa pejabat struktural pada masing-masing SKPD memiliki proporsi yang berimbang antara rentang umur 40-50 tahun dan 50-60 tahun.

Tingkat pendidikan responden pada Tabel 1 ditunjukkan pada jenjang sarjana sebanyak 162 orang $(64,03 \%)$ dan pada jenjang pasca sarjana sebanyak 73 orang $(28,85 \%)$ yang berarti bahwa kompetensi responden yang berpartisipasi dalam proses penganggaran sudah baik dan dianggap memengaruhi kemampuan, wawasan serta tingkat kepercayaan diri responden. Jenjang pendidikan juga dapat dijadikan salah satu indikator guna mengetahui tingkat pengetahuan dan intelektualitas yang dimiliki. 
Masa jabatan dijadikan acuan untuk menilai pengalaman kerja responden yang memiliki partisipasi dalam proses penganggaran pada masing-masing SKPD di Kabupaten Tabanan. Dengan pengalaman barpartisipasi dan tingkat pendidikan yang baik diharapkan responden mampu menyusun anggaran secara efektif dan efisien.

Responden merupakan pejabat struktural eselon II, eselon III, dan eselon IV yang merupakan pejabat yang berpartisipasi langsung dalam proses penganggaran dan dianggap memiliki informasi yang cukup mengenai kebutuhan dan perencanaan keuangan SKPD sesuai dengan bidang dan tanggungjawabnya, sehingga mampu memberikan informasi yang baik yang dibutuhkan dalam proses penyusunan anggaran, serta mampu memberikan jawaban pertanyaan kuesioner dengan baik.

Uji instrumen pada penelitian ini adalah dengan uji validitas dan uji reliabilitas dengan sampel sebanyak 30 responden. Uji validitas dimaksudkan untuk mengukur valid atau tidaknya suatu kuesioner. Pengujian validitas dilakukan dengan uji korelasi antar skor tiap-tiap butir pertanyaan dengan skor total variabel, sehingga diperoleh nilai pearson correlation. Pengujian signifikansi dilakukan dengan membandingkan nilai $\mathrm{r}$ hitung dengan $\mathrm{r}$ tabel pada $(\mathrm{df})=\mathrm{n}-2$, dalam hal ini $\mathrm{n}$ merupakan jumlah sampel, $\mathrm{n}=30$ dan besarnya df dapat dihitung 30-2=28, dengan $\mathrm{df}=28$ dan alpha=0,05 maka $r$ tabel $=0,3061$.

Pengujian reliabilitas merupakan pengukuran suatu kuesioner yang menjadi indikator dari variabel atau konstruk. Suatu kuesioner dikatakan reliabel atau handal apabila jawaban seseorang terhadap suatu pertanyaan adalah konsisten atau stabil dari 
I Pt. Adnyana Putra, Ni Kt. Rasmini dan IB. Putra Astika. Peran Pengendalian.......

waktu ke waktu. Rekapitulasi nilai pengujian validitas dan reliabilitas dalam penelitian ini disajikan dalam Tabel 2 .

Tabel 2

Hasil Uji Validitas dan Reliabilitas

\begin{tabular}{|c|c|c|c|c|}
\hline \multirow[t]{2}{*}{ Variabel } & \multirow[t]{2}{*}{ Indikator } & \multicolumn{2}{|c|}{ Uji Validitas } & \multirow{2}{*}{\begin{tabular}{|c|} 
Uji \\
Reliabilitas \\
$\begin{array}{c}\text { Cronbach's } \\
\text { Alpha }\end{array}$ \\
\end{tabular}} \\
\hline & & $\begin{array}{c}\text { Koefisien } \\
\text { Korelasi (r) }\end{array}$ & $\begin{array}{c}\text { Nilai } \\
\text { Signifikansi }\end{array}$ & \\
\hline Partisipasi & PP.1 & 0,817 & 0,000 & 0,806 \\
\hline \multirow{4}{*}{$\begin{array}{l}\text { Penganggaran } \\
\text { (PP) }\end{array}$} & PP.2 & 0,736 & 0,000 & \\
\hline & PP.3 & 0,892 & 0,000 & \\
\hline & PP.4 & 0,720 & 0,000 & \\
\hline & PP.5 & 0,624 & 0,000 & \\
\hline \multirow{6}{*}{$\begin{array}{l}\text { Pengendalian } \\
\text { Anggaran Ketat } \\
\text { (PAK) }\end{array}$} & PAK.1 & 0,769 & 0,000 & 0,855 \\
\hline & PAK.2 & 0,730 & 0,000 & \\
\hline & PAK.3 & 0,609 & 0,000 & \\
\hline & PAK.4 & 0,890 & 0,000 & \\
\hline & PAK.5 & 0,884 & 0,000 & \\
\hline & PAK.6 & 0,761 & 0,000 & \\
\hline \multirow[t]{14}{*}{ Etika (ET) } & ET.1 & 0,796 & 0,000 & 0,920 \\
\hline & ET.2 & 0,618 & 0,000 & \\
\hline & ET.3 & 0,725 & 0,000 & \\
\hline & ET.4 & 0,726 & 0,000 & \\
\hline & ET.5 & 0,627 & 0,000 & \\
\hline & ET.6 & 0,926 & 0,000 & \\
\hline & ET.7 & 0,701 & 0,000 & \\
\hline & ET.8 & 0,641 & 0,000 & \\
\hline & ET.9 & 0,701 & 0,000 & \\
\hline & ET.10 & 0,713 & 0,000 & \\
\hline & ET.11 & 0,733 & 0,000 & \\
\hline & ET.12 & 0,733 & 0,000 & \\
\hline & ET.13 & 0,692 & 0,000 & \\
\hline & ET.14 & 0,792 & 0,000 & \\
\hline Senjangan & SA.1 & 0,723 & 0,000 & 0,864 \\
\hline \multirow[t]{6}{*}{ Anggaran (SA) } & SA. 2 & 0,762 & 0,000 & \\
\hline & SA.3 & 0,821 & 0,000 & \\
\hline & SA.4 & 0,764 & 0,000 & \\
\hline & SA.5 & 0,745 & 0,000 & \\
\hline & SA.6 & 0,729 & 0,000 & \\
\hline & SA.7 & 0,763 & 0,000 & \\
\hline
\end{tabular}

Sumber: data diolah, 2016

Pengujian reliabilitas dalam penelitian ini menggunakan uji statistic cronbach's alpha dimana suatu variabel dikatakan reliabel jika nilai cronbach's alpha $>0,70$ 
(Ghozali, 2013). Hasil uji reliabilitas menunjukkan bahwa semua variabel mempunyai nilai Cronbach's Alpha $>0,7$.

Non-response bias perlu diuji untuk menunjukkan apakah responden yang terlambat memberi hasil yang bias dibandingkan dengan responden yang tepat waktu. Dalam penelitian ini, pengujian non-response bias dilakukan dengan memilah jawaban responden dengan memberi kode pada masing-masing kelompok jawaban seperti Tabel 3. Kode 1 merupakan data responden yang mengembalikan jawaban pada minggu pertama dan kedua setelah kuesioner disebar yaitu sebanyak 223 data responden. Kode 2 untuk data responden yang mengembalikan jawaban pada minggu ketiga setelah kuesioner disebar yaitu sebanyak 30 data responden.

Tabel 3. Pengujian Non-Response Bias Data Responden

\begin{tabular}{lcrcc}
\hline \multicolumn{1}{c}{ Variabel } & Kode & N & t & Signifikansi \\
\hline Partisipasi Penganggaran (PP) & 1 & 223 & $-0,994$ & 0,321 \\
Pengendalian Anggaran Ketat & 2 & 30 & & \\
(PAK) & 1 & 223 & 0,820 & 0,413 \\
Etika (ET) & 2 & 30 & & \\
& 1 & 223 & 1,805 & 0,076 \\
Senjangan Anggaran (SA) & 2 & 30 & & \\
& 1 & 223 & 0,525 & 0,600 \\
\hline
\end{tabular}

Sumber: data diolah, 2016

Tabel 3 menunjukkan bahwa tanggapan responden terhadap partisipasi penganggaran, pengendalian anggaran ketat, etika, dan senjangan anggaran tidak berbeda secara signifikan (two tailed test; $\mathrm{p}>0,05$ ). Maka dapat disimpulkan bahwa tidak ada non-response bias karena tidak ada perbedaan pendapat antara kelompok 1 dan kelompok 2. 
I Pt. Adnyana Putra, Ni Kt. Rasmini dan IB. Putra Astika. Peran Pengendalian.......

Analisis regresi dengan menggunakan teknik Ordinary Least Square (OLS) mensyaratkan dilakukan pengujian asumsi klasik. Pada penelitian ini pengujian asumsi klasik yang dilakukan antara lain: uji normalitas, uji multikolonieritas, dan uji heteroskedastisitas. Pengujian tersebut dilakukan guna meyakinkan model regresi yang diperoleh memiliki kamampuan memprediksi dalam pengambilan keputusan.

Pengujian normalitas dimaksudkan untuk menguji apakah dalam model regresi variabel terikat dan variabel bebas, memiliki distribusi normal atau mendekati normal. Pengujian normalitas dilakukan menggunakan nilai Kolmogorov-Smirnov. Suatu data dikatakan berdistribusi normal bila nilai signifikansi atau nilai Asymp. Sig. (2-tailed) dari nilai Kolmogorov-Smirnov > 0,05. Hasil pengujian normalitas ditunjukkan pada Tabel 4.

Tabel 4 Hasil Uji Normalitas

\begin{tabular}{|c|c|}
\hline & Unstandardized Residual \\
\hline $\mathrm{N}$ & 253 \\
\hline Kolmogorov-Smirnov Z & 0,605 \\
\hline Asymp. Sig. (2-tailed) & 0,858 \\
\hline
\end{tabular}

Sumber: data diolah, 2016

Pengujian multikolonieritas dilakukan guna menguji apakah dalam model regresi terjadi korelasi antar variabel bebas. Model regresi yang baik apabila tidak ditemukan korelasi di antara variabel bebas. Multikolonieritas terjadi bila nilai Tolerance $\leq 0,10$ atau sama dengan nilai variance inflation factor $(\mathrm{VIF}) \geq 10$. Hasil pengujian multikolonieritas ditunjukkan pada Tabel 5 . 
Tabel 5 Hasil Pengujian Multikolonieritas

\begin{tabular}{lcc}
\hline \multicolumn{1}{c}{ Variabel } & Tolerance & VIF \\
\hline Partisipasi Penganggaran (PP) & 0,636 & 1,571 \\
Pengendalian Anggaran Ketat (PAK) & 0,618 & 1,617 \\
Etika (ET) & 0,655 & 1,526 \\
\hline
\end{tabular}

Sumber: data diolah, 2016

Tabel 5 menunjukkan tidak ada variabel bebas yang memiliki nilai Tolerance $<0,1$ dan nilai TIF $>10$. Sehingga dapat disimpulkan tidak ada multikolonieritas antar variabel bebas dalam model regresi.

Pengujian heterokedastisitas dimaksudkan untuk menguji apakah dalam model regresi terjadi ketidaksamaan varians dari residual satu pengamatan ke pengamatan yang lain (Ghozali, 2013). Pengujian heterokedastisitas dilakukan dengan uji Glejser, dengan cara meregresi nilai absolut residual dari model yang diestimasi terhadap variabel bebas. Hasil pengujian heterokedastisitas disajikan pada Tabel 6 .

Tabel 6 Hasil Uji Heterokedastisitas

\begin{tabular}{lcc}
\hline \multicolumn{1}{c}{ Variabel } & t & Sig. \\
\hline Partisipasi Penganggaran (PP) & 0,297 & 0,767 \\
Pengendalian Anggaran Ketat (PAK) & 1,322 & 0,187 \\
Etika (ET) & 1,375 & 0,170 \\
\hline
\end{tabular}

Sumber: data diolah, 2016

Tabel 6 menunjukkan bahwa tidak ada variabel bebas yang berpengaruh signifikan terhadap variabel terikat Absolute Residual (Absres). Ini dibuktikan dengan nilai signifikansi sebesar 0,767 untuk variabel partisipasi penganggaran, 0,187 untuk variabel pengendalian anggaran ketat, dan 0,170 untuk variabel etika. Nilai-nilai tersebut lebih besar dari nilai alpha $(\alpha=0,05)$, sehingga dapat disimpulkan pada model regresi tidak ditemukan gejala heterokedastisitas. 
I Pt. Adnyana Putra, Ni Kt. Rasmini dan IB. Putra Astika. Peran Pengendalian.......

Statistik deskriptif digunakan untuk memberikan informasi tentang karakteristik variabel penelitian, antara lain nilai minimum, nilai maksimum, mean, dan standar deviasi. Statistik deskriptif pada penelitian ini terdapat dalam Tabel 7.

\begin{tabular}{lcrrrr}
\multicolumn{7}{c}{ Tabel 7 } & & \\
& Statistik Deskriptif & Data Uji & \\
\hline \multicolumn{1}{c}{ Variabel } & \multicolumn{1}{c}{ N } & \multicolumn{1}{c}{ Min } & \multicolumn{1}{c}{ Maks } & Rata-rata & Std. Deviasi \\
\hline Partisipasi Penganggaran (PP) & 253 & 5,00 & 20,26 & 15,7899 & 4,28790 \\
Pengendalian Anggaran Ketat & 253 & 6,00 & 28,23 & 19,8973 & 4,30723 \\
(PAK) & & & & & \\
Etika (ET) & 253 & 16,36 & 75,26 & 45,8822 & 9,43432 \\
Senjangan Anggaran (SA) & 253 & 8,82 & 32,01 & 23,7381 & 4,70759 \\
Interaksi PP*PAK & 253 & 39,57 & 571,87 & 324,2021 & 121,82410 \\
Interaksi PP*ET & 253 & 81,78 & 1343,91 & 744,8004 & 274,17357 \\
\hline
\end{tabular}

Sumber: data diolah, 2016

Pada Tabel 7 secara keseluruhan nilai deviasi standar tidak ada yang melebihi dua kali nilai rata-rata. Hal tersebut menandakan sebaran data sudah baik. Widanaputra (2007) menyatakan bila nilai deviasi standar dari variabel penelitian tidak melebihi dua kali nilai rata-rata maka sebaran data dapat dikatakan baik. Nilai rata-rata menunjukkan tendensi pusat dari distribusi data yang digunakan pada penelitian ini. Nilai deviasi standar menunjukkan variabilitas data terhadap pusatnya.

Pengujian hipotesis pada penelitian ini diuji menggunakan uji analisis regresi moderasi (Moderated Regression Analysis/MRA). Hasil analisis MRA ditampilkan dalam Tabel 8.

Hasil analisis regresi moderasi menunjukkan 63,9 persen variabel partisipasi penganggaran yang dimoderasi oleh pengendalian anggaran ketat dan etika mampu menjelaskan variabel senjangan anggaran yang ditunjukkan oleh nilai Adjusted R square sebesar 0,639, sedangkan sebesar 36,1 persen dijelaskan oleh variabel lain 
yang tidak dimasukkan dalam model. F test menunjukkan nilai $\mathrm{F}_{\text {hitung }}$ sebesar 90,152 signifikansi 0,000 yang berarti model dalam penelitian ini layak (fit) dan pembuktian hipotesis dapat dilanjutkan.

Tabel 8

Hasil Uji Moderated Regression Analysis

\begin{tabular}{|c|c|c|c|c|c|}
\hline \multirow{2}{*}{ Variabel } & \multicolumn{2}{|c|}{$\begin{array}{l}\text { Unstandardized } \\
\text { Coefficients }\end{array}$} & \multirow{2}{*}{$\begin{array}{c}\begin{array}{c}\text { Standardized } \\
\text { Coefficients }\end{array} \\
\text { Beta }\end{array}$} & \multirow{2}{*}{$\mathbf{t}$} & \multirow{2}{*}{ Sig. } \\
\hline & B & $\begin{array}{l}\text { Std. } \\
\text { Error }\end{array}$ & & & \\
\hline Konstanta & $-9,131$ & 2,763 & & $-3,305$ & 0,001 \\
\hline $\begin{array}{l}\text { Partisipasi Penganggaran } \\
\text { (PP) }\end{array}$ & 1,326 & 0,192 & 1,208 & 6,909 & 0,000 \\
\hline $\begin{array}{l}\text { Pengendalian Anggaran } \\
\text { Ketat (PAK) }\end{array}$ & 0,684 & 0,143 & 0,626 & 4,798 & 0,000 \\
\hline Etika (ET) & 0,363 & 0,073 & 0,727 & 4,952 & 0,000 \\
\hline PP*PAK & $-0,018$ & 0,009 & $-0,454$ & $-1,857$ & 0,045 \\
\hline PP*ET & $-0,017$ & 0,005 & $-0,988$ & $-3,730$ & 0,000 \\
\hline $\mathrm{F}$ & 90,152 & & & & \\
\hline Sig. F & 0,000 & & & & \\
\hline R Square & 0,646 & & & & \\
\hline Adjusted R Square & 0,639 & & & & \\
\hline
\end{tabular}

Dari Tabel 8 persamaan regresi dapat disusun adalah sebagai berikut :

$\mathrm{SA}=-9,131+1,326 \mathrm{PP}+0,684 \mathrm{PAK}+0,363 \mathrm{ET}-0,018 \mathrm{PP} * \mathrm{PAK}-0,017 \mathrm{PP} * \mathrm{ET}+\mathrm{e}$

Penelitian ini menguji peran pengendalian anggaran ketat dan etika sebagai variabel moderasi pengaruh partisipasi penganggaran pada senjangan anggaran. Hipotesis pertama menyatakan pengendalian anggaran ketat memperlemah pengaruh partisipasi penganggaran pada senjangan anggaran. Hasil analisis regresi menunjukkan nilai koefisien beta sebesar -0,018 dengan angka probabilitas sebesar $0,045<0,05$ yang berarti pengendalian anggaran ketat mampu memperlemah pengaruh partisipasi penganggaran pada senjangan anggaran, dalam artian semakin tinggi tingkat pengendalian anggaran maka senjangan anggaran akan dapat 
I Pt. Adnyana Putra, Ni Kt. Rasmini dan IB. Putra Astika. Peran Pengendalian.......

diminimalkan. Hal tersebut ditunjukkan juga oleh rata-rata jawaban responden yang merupakan pejabat struktural di tiap-tiap SKPD untuk variabel pengendalian anggaran ketat yang berada pada klasifikasi baik. Hal ini dapat diartikan apabila SKPD konsisten menerapkan pengendalian anggaran dalam penyusunan anggaran maka senjangan anggaran dapat diturunkan.

Pengendalian anggaran adalah mekanisme yang diterapkan secara luas dalam menilai kinerja subordinate, untuk mengkomunikasikan tujuan, strategi, dan proses perencanaan, serta bagaimana organisasi mampu mendapat hasil yang diinginkan dengan memantau pengeluaran. Hal ini juga digunakan sebagai instrumen untuk mengolah serta membentuk perilaku individu agar selaras dengan tujuan organisasi (Hemsing dan Baker, 2013). Pengendalian anggaran ketat (tight budgetary control) seringkali dikaitkan dengan timbulnya perilaku disfungsional. Agency theory menjelaskan bahwa tujuan prinsipal dan tujuan agen yang berbeda dapat menimbulkan konflik. Agen dalam hal ini pimpinan organisasi cenderung mengejar tujuan pribadi untuk menunjukkan kinerja yang baik dalam hal pencapaian target anggaran. Untuk memudahkan pencapaian target anggaran, pimpinan organisasi seringkali melakukan perilaku menyimpang dalam hal penyusunan anggaran berupa senjangan anggaran. Sebaliknya dari sisi prinsipal, untuk mencegah penyimpangan dalam penganggaran yang dilakukan oleh agen hendaknya diberlakukan sistem pengendalian yang ketat, hal ini didukung temuan Yilmaz dan Ozer (2011a dan b) 
yang menyatakan bahwa terdapat hubungan negatif antara efektivitas pengendalian anggaran dengan kecenderungan untuk menciptakan senjangan anggaran.

Hasil penelitian ini konsisten dengan hasil penelitian Murdijaningsih (2003), Novitasari (2015), yang menemukan adanya pengaruh pengendalian anggaran terhadap senjangan anggaran.

Hipotesis kedua penelitian menyatakan etika pegawai memperlemah pengaruh partisipasi penganggaran pada senjangan anggaran. Hasil analisis regresi menunjukkan nilai koefisien beta $-0,017$ dengan nilai probabilitas sebsear $0,000<$ 0,05 yang berarti bahwa etika mampu memperlemah pengaruh partisipasi penganggaran terhadap senjangan anggaran. Semakin baik etika yang dimiliki oleh pihak-pihak yang ikut berpartisipasi dalam penyusunan anggaran maka senjangan anggaran akan cenderung menjadi lebih rendah. Hal ini sesuai dengan teori yang dinyatakan oleh Blocher dkk. (2000) yang menyatakan etika diperlukan untuk meningkatkan tanggungjawab pada penyusunan dan pelaksanaan anggaran dalam rangka pencapaian tujuan organisasi.

Etis tidaknya keputusan seseorang dipengaruhi oleh faktor individual dan faktor situasional (Ford dan Richardson, 1984). Responden yang menganggap adanya senjangan anggaran sebagai hal yang tidak etis maka semakin rendah kecenderungan untuk menciptakan senjangan anggaran, sebaliknya semakin responden menganggap adanya senjangan anggaran sebagai hal yang etis maka semakin meningkatkan kecenderungan untuk menciptakan senjangan anggaran. Faktor individual 
I Pt. Adnyana Putra, Ni Kt. Rasmini dan IB. Putra Astika. Peran Pengendalian.......

membuktikan bahwa kapasitas individu memiliki pengaruh positif terhadap keputusan etis individu dalam kaitannya dengan budgetary slack. Hal ini bisa diinterpretasikan bahwa semakin tinggi tingkat pendidikan seseorang maka semakin positif atau semakin etis juga pandangannya terhadap budgetary slack. Blanchete, et al. (2002) menyatakan bahwa budgetary slack merupakan sesuatu yang etis dengan asumsi bahwa adanya budgetary slack maka pimpinan akan menjadi lebih kreatif, lebih bebas dalam melakukan aktivitasnya serta mampu mengantisipasi ketidakpastian.

Hasil penelitian ini konsisten dengan hasil penelitian dengan Maskun (2009), Triadhi (2013) dan Biantara (2014) yang menemukan adanya pengaruh etika terhadap senjangan anggaran atau budgetary slack. Responden yang menganggap adanya senjangan anggaran sebagai hal yang kurang etis maka akan semakin mengurangi kecenderungan untuk membuat senjangan anggaran, sebaliknya senjangan anggaran yang dipandang sebagai hal wajar akan semakin meningkatkan adanya senjangan anggaran.

\section{SIMPULAN DAN SARAN}

Simpulan dalam penelitian ini, yaitu: 1) Pengendalian anggaran ketat dapat memperlemah pengaruh partisipasi penganggaran pada senjangan anggaran. Pengendalian anggaran ketat dapat dijadikan sebagai salah satu instrumen untuk menurunkan tingginya senjangan anggaran pada penganggaran pemerintah daerah. 2) Etika dapat memperlemah pengaruh partisipasi penganggaran pada senjangan 
anggaran. Etika dianggap sebagai faktor internal yang mampu menurunkan kecenderungan keinginan individu untuk menciptakan senjangan anggaran karena motivasi untuk mementingkan diri sendiri. Semakin baik etika yang dimiliki individu akan mampu menurunkan terjadinya senjangan anggaran.

Saran penelitian ini, antara lain: 1) Dampak yang timbul akibat proses partisipasi dalam penyusunan anggaran berupa senjangan anggaran yang tinggi. Oleh karena itu, penting bagi Pemerintah Kabupaten Tabanan untuk meningkatkan koordinasi dan komunikasi antara pihak-pihak yang terlibat dalam proses penyusunan anggaran seperti pejabat esellon II, esellon III dan esellon IV di tiap-tiap SKPD sehingga terjadi sinergitas tujuan yang sama untuk meningkatkan produktivitas, efisiensi, dan kualitas penganggaran agar menjadi efektif dan efisien. 2) Penelitian ini memberikan simpulan bahwa variabel pengendalian anggaran ketat dan etika mampu menurunkan pengaruh partisipasi penganggaran pada senjangan anggaran. Pengendalian anggaran ketat dapat diinterpretasikan berupa monitoring dan evaluasi proses penyusunan anggaran. Untuk target pendapatan perlu dibuat data terkait potensi pendapatan daerah, dan untuk target belanja perlu disusun analisis standar biaya sebagai acuan penyusunan anggaran. Dengan data tersebut diharapkan senjangan anggaran yang terjadi dapat diminimalkan. 3)Penelitian ini mengukur variabel-variabel yang diteliti menggunakan instrumen berupa persepsi jawaban responden, sehingga bukan tidak mungkin menimbulkan masalah bias jika persepsi responden tersebut berbeda dengan keadaan yang sesungguhnya. Penelitian 
I Pt. Adnyana Putra, Ni Kt. Rasmini dan IB. Putra Astika. Peran Pengendalian.......

selanjutnya yang berkaitan dengan partisipasi penganggaran dan senjangan anggaran, perlu mempertimbangkan faktor-faktor lain yang dapat memengaruhi timbulnya senjangan anggaran dan juga mampu mengurangi terjadinya senjangan anggaran, menggunakan teknik pengukuran yang lain misalnya dengan penelitian berupa eksperimen, karena penelitian eksperimen memiliki kelebihan, yaitu: kemampuan untuk membuktikan ada tidaknya hubungan sebab akibat yang dihasilkan pada penelitian eksperimen dibandingkan penelitian non-eksperimen, dan kemampuan memanipulasi secara tepat satu atau lebih variabel yang diinginkan peneliti (Christensen, 2001).

\section{REFERENSI}

Anthony, R.N. dan Govindarajan, V. 2006. Sistem Pengendalian Manajemen. (FX. Kurniawan Tjakrawala, Penerjemah). Salemba Empat. Jakarta.

Argyris, C. 1952. The Impact of Peoplt: on Budgets. New York, NY: Contollership Foundation.

Biantara, A. A. A., Putri, D., \& Asri, I. A. 2014. Pengaruh Kejelasan Sasaran Anggaran, Etika, dan Kepercayaan Diri pada Senjangan Anggaran. E-Jurnal Akuntansi, 9(2), 385-391.

Blanchete, D., Claude, P., and Jean, C. 2002. Manager's Moral Evaluation of Budgetary Slack Creation. The Accounting Review. Vol 26: 141-162.

Blocher, E.J, Chen, K.H, Lin, T.W. 2000. Manajemen Biaya. Salemba Empat. Jakarta.

Brownell, P. 1982. The Role of Accounting Data in Performance Evaluation, Budgetary Participation, and Organizational Effectiveness. Journal of Accounting Research 20 (Spring): pp. 12-27.

Chenhall, R. H., \& Brownell, P. 1988. The effect of participative budgeting on job satisfaction and performance: Role ambiguity as an intervening variable. Accounting, Organizations and Society, 13(3), 225-233. 
Dunk, A.S. 1993. The Effect of Budget Emphasis and Information Asymetry on the Relation Between Budgetary Participation and Slack. The Accounting Review 68. April. Pp. 400-410.

Ghozali, I. 2012. Analisis Data Multivariate dengan Program IBM SPSS 20. Edisi 6. Badan Penerbit Universitas Diponegoro. Semarang.

Hemsing, M., \& Baker, F. 2013. The Effects of Tight Budgetary Control on Managerial Bahaviour in the Swedish Public Sector: Emphasizing Motivation, Commitment, Satisfaction and Stress. Business Administration Karlstad Univertisty.

Hidayani, S., \& Nila, A. 2012. Pengaruh Partisipasi Penyusunan Anggaran, Informasi Asimetri, Budget Emphasis dan Komitmen Organisasi terhadap Timbulnya Budgetary Slack Aparat Pemerintah Bengkulu (Study Empiris pada SKPD Pemerintah Kota Bengkulu). tesis, Fakultas Ekonomi UNIB.

Latuheru, B.P. 2006. Pengaruh Partisipasi Anggaran terhadap Senjangan Anggaran dengan Komitmen Organisasi sebagai Variabel Moderating (Studi Empiris pada Kawasan Industri Maluku). Jurnal Akuntansi dan Sistem Teknologi Informasi. Volume 5, No. 1.

Lukka, K. 1988. Budgetary Biasing in Organizations: Theoritical Framework and Empirical Evidence. Accounting, Organization, and Society 13. Pp. 281-301.

Mardiasmo, 2009. Akuntansi Sektor Publik, Edisi ke empat. Yogyakarta: Andi Offset.

Maskun, A. 2009. Analisis Faktor Etika, Budaya Birokrasi, Tekanan Sosial dan Kapasitas Individu terhadap Budgetary Slack (Senjangan Anggaran) (Kajian Perilaku Eksekutif Dalam Proses Penyusunan Anggaran Di Badan Koordinator Wilayah II Jawa Timur). Jurnal Aplikasi Manajemen, 7(1), 162-172.

Merchant, K. A. 1985. Budgeting and Propensity to Create Slack. Accounting Organization and Society.

Milani, K. 1975. The Relationship of Participation in Budget-Setting on Industrial Supervisor Performance and Attitudes: A Field Study. The Accounting Review 50. Pp. 104-123. April.

Murdijaningsih, T. 2003. Hubungan Antara Dua Konsekuensi Pengendalian Anggaran: Kelonggaran Anggaran dan Orientasi Manajerial Jangka Pendek. (tesis). Program Pascasarjana Universitas Diponegoro.

Novitasari, N., \& Wirama, D. G. 2016. Pengaruh Pengendalian Anggaran pada Senjangan Anggaran dan Orientasi Jangka Pendek Manajer. E-Jurnal Akuntansi, 15(3), 2024-2051. 
I Pt. Adnyana Putra, Ni Kt. Rasmini dan IB. Putra Astika. Peran Pengendalian.......

Onsi, M. 1973. Factor Anaysis of Behavioral Variables Affecting Budgetary Slack. The Accounting Review. Juli. Pp. 535-548.

Rasuli, M. dan Yunus, H. 2002. Hubungan Dua Konsekuensi Pengendalian Anggaran: Penciptaan Slack Anggaran dan Orientasi Manajerial Berjangka Pendek: Studi Empiris Pada BUMN Indonesia. Jurnal dan Prosiding SNA - Simposium Nasional Akuntansi. Vol. 5.

Schiff. M., and Lewin. A.Y. 1970, The Impact of People on Budgets. The Accounting Review. pp: 259-267.

Sugiyono. 2014. Metode Penelitian Bisnis: Pendekatan Kuantitatif, Kualitatif dan R\&D, Cetakan ke-18. Bandung: Alfabeta.

Setyorini, N., Hasthoro, H. A., \& Wicaksono, A. 2013. Partisipasi Anggaran Pada Sektor Publik. Efektif Jurnal Bisnis dan Ekonomi, Vol. 25, 2, 137-148.

Sujana, I. K. 2010. Pengaruh Partisipasi Penganggaran, Penekanan Anggaran, Komitmen Organisasi, Asimetri Informasi, dan Ketidakpastian Lingkungan terhadap Budgetary Slack pada Hotel-Hotel Berbintang di Kota Denpasar. Jurnal Ilmiah Akuntansi dan Bisnis, 5(2).

Supanto, S. 2010. "Analisis Penagruh Partisipasi Penganggaran terhadap Budgetary Slack dengan Informasi Asimetri, Motivasi, Budaya Organisasi sebagai Pemoderasi” (tesis), Universitas Diponegoro.

Triadhi, N. A. 2014. Pengaruh Preferensi Risiko, Etika dan Partisipasi Penyusunan Anggaran Pendapatan di Pemerintah Daerah Provinsi Bali. E-Jurnal Ekonomi dan Bisnis Universitas Udayana, 3(06).

Widanaputra, A. A., \& Mimba, N. P. S. H. (2014). The influence of participative budgeting on budgetary slack in composing local governments' budget in Bali province. Procedia-Social and Behavioral Sciences, 164, 391-396.

Yilmaz, E. and Ozer, G. 2011. Effects of Procedural Justice Perception, Budgetary Control Effectiveness and Ethical Work Climate on Propensity to Create Budgetary Slack. Business and Economics Research Journal. Volume 2 Number 4 pp. 1-18.

Young, S.M. 1985. Participatif Budgeting: The Effect of Risk Aversion and Asymetric Information on Budgetary Slack. J. Account. Res. 23(2): 829-842. 